\title{
Memórias do cárcere no livro e na tela: arte versus ditadura
}

Erwin Torralbo Gimenez ${ }^{I}$

"E depois? Que viria depois? O caos, provavelmente. Se os defensores da ordem a violavam, que devíamos esperar? Confusão e ruína. Desejando atacar a revolução, na verdade trabalhavam por ela. Era por isso talvez que o bacharel Nunes Leite chorava.”

(Graciliano Ramos)

E M SEU SEGUNDO ensaio sobre Graciliano Ramos - o primeiro é o insigne Ficção e confissão -, Antonio Candido considera um vínculo latente a unir os livros sob a visão do escritor. Tanto nos romances quanto nas recordações, haveria um senso de emparedamento, espécie de assombro que, difuso no tempo, estrangula a subjetividade, tornando-a dramática. Memórias do cárcere, testemunho final, concentraria, logo, ao narrar a experiência da cadeia, essa gravidade trágica, ora absorvida como "dimensão própria do século dos totalitarismos". Completa-se assim, graças à aprendizagem concreta e à escrita laboriosa, aquele olhar já antes negativo do autor, cuja compreensão também se amplia, pois “os acontecimentos fizeram Graciliano Ramos passar do mundo como prisão à prisão enquanto mundo" (Candido, 1960). ${ }^{1}$

Com efeito, a cada episódio o depoente se esforça por romper a superfície dos fatos, à medida que investiga o íntimo das personagens (inclusive de si mesmo) e corrige todo juízo precipitado. Vemos o trabalho de uma inteligência séria, que envolve os objetos ao seu redor, atinge o miolo das ideias e apanha os matizes mais fugidios. Parte-se da generalidade ordinária, pouco ou nada aderente ao indivíduo, para descobrir, na análise do singular, os sinais que se universalizam na história. E o ponto de vista se apura. Para trazer aqui um exemplo: no capítulo 13 do volume I, Graciliano Ramos se espanta com o choro convulso do bacharel Nunes Leite, a quem a carceragem devasta enormemente; presume estar ali um homem enfermo, suscetível a abalos extremos e disparates nervosos; mas depois pondera a diferença entre os caracteres, afinal isso a ordem sempre ignora. Nunes Leite não era um maníaco, apenas não sabia existir fora dos regulamentos, daí o despropósito; em contrapeso, havia quem se acomodasse sereno atrás das grades. E a conclusão do memorista salta da circunstância ao sistema desfigurador de perfis: "A administração pública não atenta nessas ninharias, tende a uniformizar as pessoas. Somos grãos que um moinho tritura - e ninguém quer saber se resistimos à mó ou se nos pulverizamos logo" (Ramos, 1953). O discurso, já em clave plural e presente, revela o apagamento dos sujeitos pela disciplina do mundo, repressora, em tempos modernos, independentemente da região a analogia com o moinho, a esmigalhar a matéria mais dura ou menos dura, é a síntese dessa impressão estilhaçada que nos ronda a todos, grãos diluídos na massa. Todavia, avaliar, após vários anos, o desastre e formar sobre ele um ângulo avesso ainda impõem um obstáculo à moenda. 
Mesmo antes das memórias, em 1942, Carpeaux salientava o anarquismo como pulso ideológico do autor, contrário radicalmente às coisas do mundo, mas também inquieto por salvá-lo na criação artística. As sombras que ofuscam o ambiente de seus romances se projetam "do edifício da nossa civilização artificial - cultura e analfabetismo letrados, sociedade, cidade, Estado, todas as autoridades temporais e espirituais" (Carpeaux, 1968). Esses produtos falhos da história precisariam sumir, para que se erguesse nova realidade, só tecida no drama pela fresta do delírio. No fundo, a recusa abrange todo o lastro das estruturas sociais, iníquas e corruptas, porque em seus corredores se aniquila a identidade - e nos regimes de tirania, o arbítrio sobe ao plano do terror. Muito além de construir um relato acerca da ditadura varguista, o testemunho exprime as reflexões de uma consciência sob as ruínas no "século dos totalitarismos" e, por isso, representa uma contra-voz no meio do infortúnio. ${ }^{2}$

O estilo de Graciliano Ramos, na dialética de um realismo sui generis, atravessa a aparência dos acontecimentos; subsiste e até se eleva com o decorrer da história, a qual costuma reencenar as mesmas farsas e tragédias. Ocorre-me recuperar esse conceito em razão do estudo Memórias do Cárcere: da literatura ao cinema, de Paulo Roberto Ramos (2019), cujo núcleo se firma justamente no poder de significado da obra, seja como escrita, seja como filme, comunicando ao público, em diversos momentos, a resistência perante códigos autoritários: "Ao transpor as recordações de Graciliano, Nelson Pereira utiliza-se delas para dialogar não apenas com o livro, mas com o contexto do regime militar que controlava o país desde 1964 e que, na época em que a película foi realizada, em 1984, exalava seus últimos suspiros" (p.12) Cabe, sem dúvida, acrescentar uma terceira margem, pertencente ao domínio crítico, o próprio ensaio que, hoje, denuncia a tenacidade da injustiça. Tais esferas se articulam em torno dos eixos arte e despotismo, naturalmente antagônicos, e deságuam na ideia do receptor - do livro, da fita e da pesquisa -, chamado a repensar o fluxo entre a cultura e a sociedade.

Não se trata, assim, de simples exame comparativo dos moldes de invenção que partilham, nesse caso, um material verídico. Paulo Roberto se empenha em observar, atento aos expedientes formais peculiares a cada linguagem, os efeitos de representação daquele material nos distintos períodos em que se elaboram e sua extensão ao longo do tempo. Para tanto, mobiliza aspectos teóricos da crítica literária, da cinematografia, da filosofia e da militância política a fim de apreender a refração dos eventos: de um lado, operada pelo corte autobiográfico, que se faz no limite de um depoente, e de outro, a adaptação fílmica, menos fiel à peça matriz do que o leitor talvez esperasse, para, contudo, traduzir a mensagem em novo feitio. Em ambos, interessa ver a afinidade de dois criadores inconformados com o clima de abafamento que as forças armadas imprimem em quadras de exceção no país. Aliás, as obras são penetrantes a ponto de acusarem o teor não inteiramente excepcional dessas épocas, pois elas assinalam apenas fases mais agudas de um processo - daí a seqüência crítica aqui esboçada: da tradição brasileira dentro da barbárie moderna, percutindo nas ditaduras explícitas e nos raios de um círculo histórico, até hoje. 


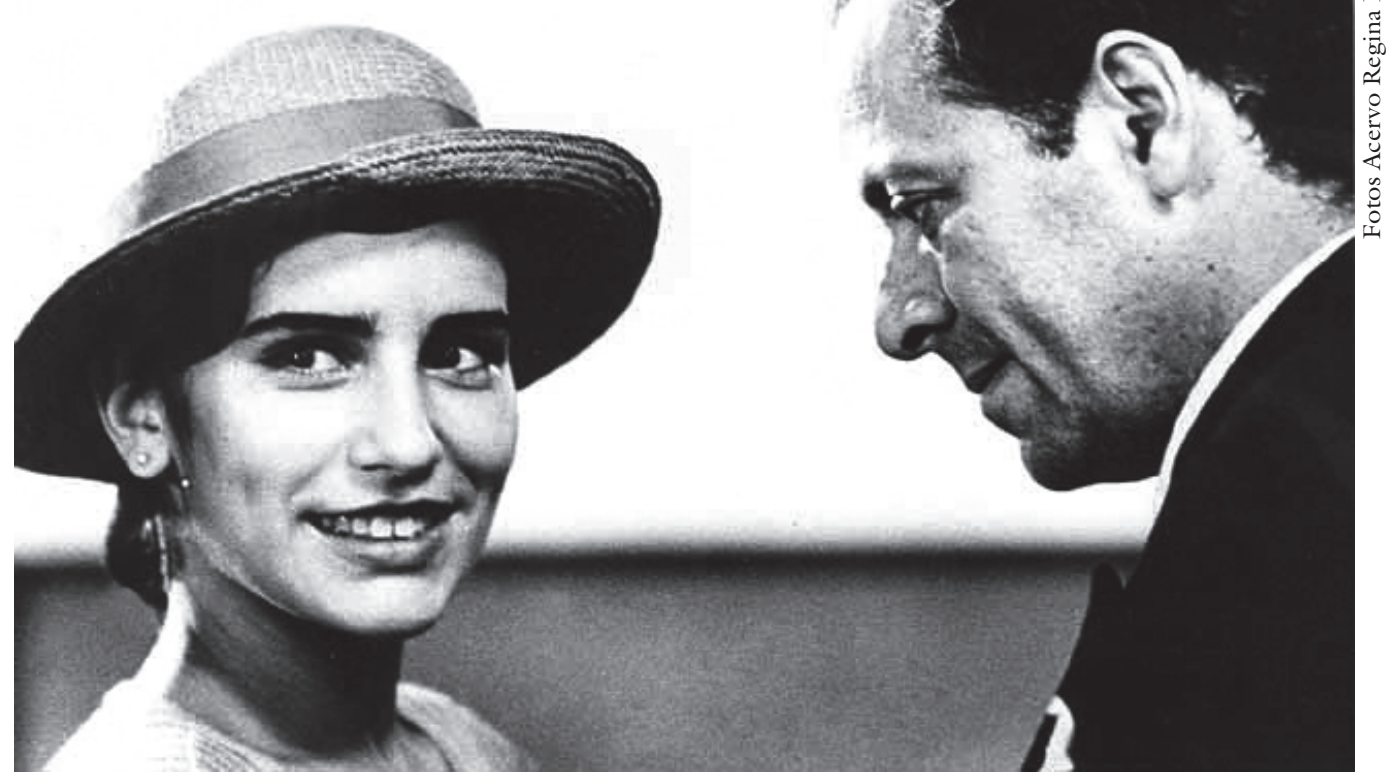

Memórias do cárcere (1983): Glória Pires (Heloisa) e Carlos Vereza (Graciliano Ramos).

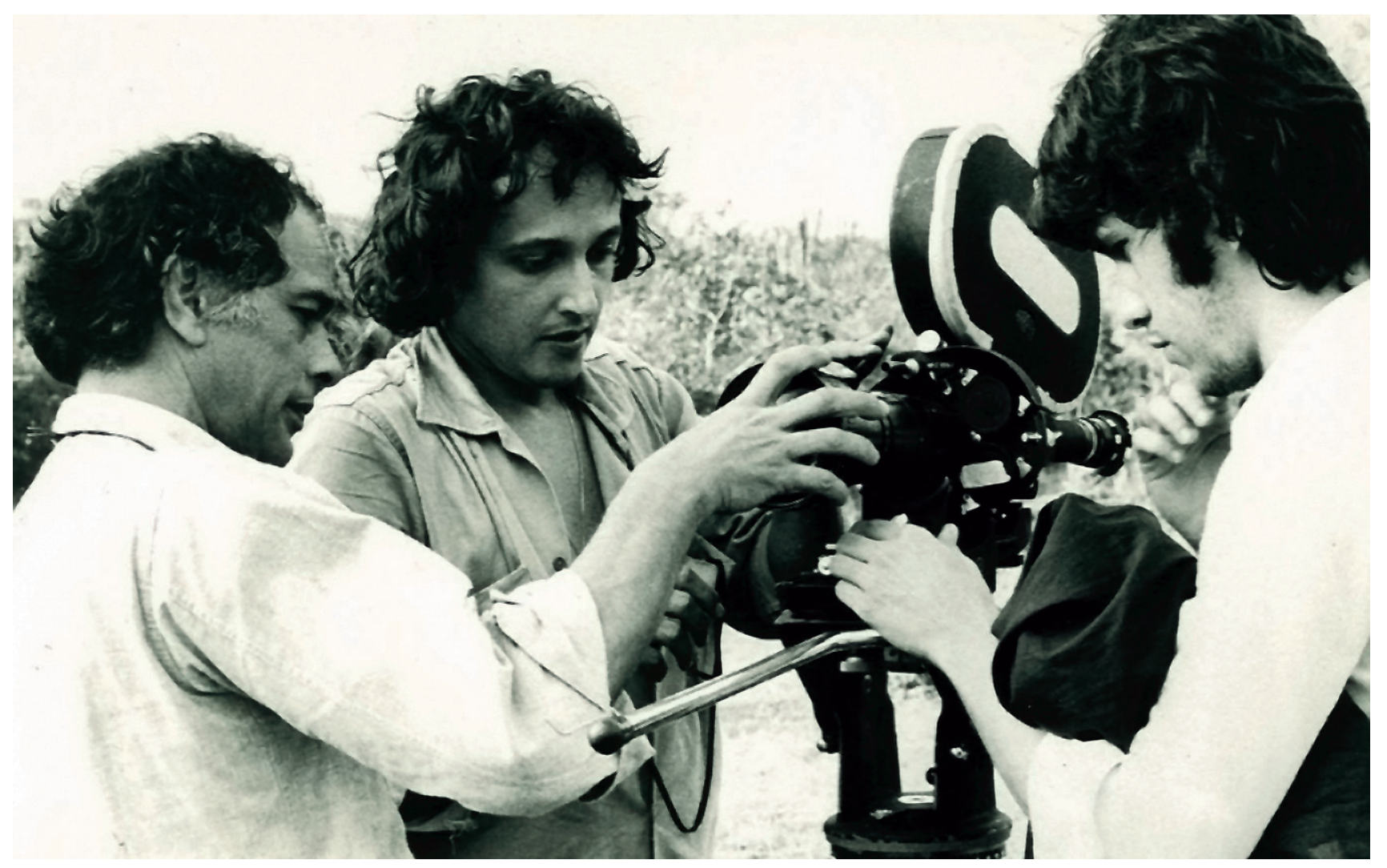

O cineasta Nelson Pereira dos Santos (à esq.) nas gravações de O amuleto de Ogum (1973-1974). 
A estratégia da pesquisa consiste em traçar panoramas de contexto e derivar então para a análise dos objetos, sublinhando sempre o paralelo entre as perspectivas. Ao estudar os motivos de tensão social recorrentes, adverte o veio das fraturas nacionais que muito pouco se alteram no passo das décadas. Isso permite ao cineasta, por exemplo, arranjar na tela um enredo escrito 25 anos antes, no qual se figura a má sina do retirante, com o intuito de sugerir a persistência da mazela sertaneja. É o caso do filme Vidas Secas, de 1963: "o realizador serviu-se de uma narrativa sobre o passado para falar sobre o presente" (p.149). Às voltas com o governo militar, Nelson Pereira dos Santos repete, anos mais tarde, o jogo de espelhos, desvia-se do censor obtuso e instiga a plateia a discernir os reflexos que se lançam de lá para cá: "Para o público dos cinemas em 1984, que, em menor ou maior grau, tinha algum conhecimento das ações nos porões da ditadura, as cenas associadas à tortura em Memórias do Cárcere apontam para a traumática história recente do país, construída, nas últimas duas décadas, por um regime que ainda governava seus espectadores" (p.173). Cumpre realçar que as duas obras resultam, nos itinerários dos seus autores, de uma mais larga abertura da sensibilidade ao outro, quando as vicissitudes thes inculcaram uma visão lúcida e os aproximaram dos humildes, vítimas todos de igual violência: na cadeia, Graciliano ganhou o convívio direto com os miseráveis, derrubou as barreiras de classe e de intelecto; à procura do retrato popular, Nelson Pereira se fraternizou com as camadas pobres já longe da óptica do Cinema Novo, durante o decênio de 1970.

Merecem destaque, no conjunto do trabalho, as passagens de mais detida análise, capazes de acompanhar os elementos confluentes ou específicos que distinguem as técnicas de narração. Examinando os espaços, constata-se a mudança de enfoques provocada pela atitude a um só tempo vigilante e discreta do sujeito, carregado de um lugar para outro segundo um roteiro absurdo. Se no livro tal atmosfera se trama com o estilo sombrio de Graciliano, na película o cineasta se vale dos recursos de seu ofício, no manejo da câmera. Nas fumaças do porão do Manaus, navio de transporte dos presos, a lente captura as nuances da noite infernal rente ao olhar da testemunha: "Tudo o que é mostrado pelo dispositivo é mediado pela presença do protagonista na cena e, em alguns casos, de forma subjetiva, quando ela assume explicitamente seu ponto de vista - tal característica está presente na maior parte dos planos do filme" (p.130). Talvez ainda mais expressivo, em termos de análise, seja o capítulo a respeito da música. Ademais de registrar as paródias e sambas soantes no porão, espécie de coro de verve revolucionária, o crítico anota com minúcia o andamento em escalas que o narrador grava nesse trecho, compondo quase uma pauta reverberadora das ondas rítmicas, flutuantes do repouso à vigília. E, na fita, ressalta o emprego magnífico que Nelson Pereira faz da "Marcha solene brasileira", de Gottschalk, para insinuar os acordes na vertigem emocional do prisioneiro: "Cada vez que a ouvimos, da janela do Palácio do Governo de Alagoas à embarcação que deixa a Colônia Correcional, ela assinala a descida do personagem para ambientes cada vez mais duros e degradados" (p.196).

Graciliano Ramos devotou os últimos 
sete anos de sua existência às Memórias do cárcere (1946-1953), evocando os onze meses de confinamento sofridos de março de 1936 a janeiro de 1937. O intervalo decantou, sem dúvida, a compreensão sobre o vivido e abriu vez aos meios de expressão - essa busca, aliás, foi difícil: o autor redigiu várias notas enquanto detido, mas teve de inutilizá-las, e ainda tentou em vão dar forma às reminiscências logo após a soltura. E a morte lhe impediu forjar as páginas finais (faltava somente um capítulo), suspendendo o entrecho antes da liberdade; quem sabe se tal lacuna não se ajusta melhor ao espírito da obra, na qual se lê no início: "liberdade completa ninguém desfruta". Para render homenagem ao escritor e arrumar um epílogo, Nelson Pereira resolveu fabricar um remate simbólico. Ao invés de exibir Graciliano a abandonar os manuscritos, lançando-os à água do mar ou ocultando-os sob o colchão, planeia uma cena de congraçamento do intelectual com os companheiros, como a sugerir a aliança potencialmente remissória das letras com o povo: os papéis não se perdem, distribuem-se entre os detentos, cada um passa a ser portador de uma folha - talvez o futuro as reunisse. E o artista parece marchar rumo à liberdade.

Um jovem literato alagoano chega ao Rio de Janeiro em 1914 com a veleidade de fazer carreira na capital. Observador sagaz, perambula pela cidade grande e espreita os costumes no curso intenso que as coisas agora oferecem ao migrante vindo da província. Em crônica a propósito de cinemas, diz: "Esses agradáveis lugares onde a gente se educa, vendo as reproduções de fatos que nunca se passaram" (Ramos, 1970). ${ }^{3}$ A ironia leve apanha a cadência de alienação e mimetismo naquele princípio de século, quando os dramalhões estrangeiros empolgavam a fantasia das plateias. Mas importa acima disso reconhecer em sua gênese a demanda realista do autor, consciente de que fatos não se imaginam nem tampouco a mera cópia deles basta; é preciso interpretá-los numa imitação significativa. Não supunha, porém, o jovem a carga de reveses em seu destino, e menos ver palavras de sua tinta se transferirem às telas, num rigor estético já muito diferente dos melodramas. Decerto, o homem maduro refinaria aquela primeira noção de realismo, pois aprendeu com o tempo que os fatos não se passam, mas, sim, se reproduzem de acordo com a particularidade do olhar. Com isso, as Memórias do cárcere, livro e filme, constituem duas obras, compostas por duas autorias; é o que nos leva a pensar a mirada relativista de Graciliano Ramos, no rascunho de 1937:

Está claro que não tenho o intuito de contar como as coisas se passaram. Direi como as coisas me apareceram. Muitas narrativas foram ou serão feitas sobre os mesmos acontecimentos a que me refiro. É provável que saiam diferentes umas das outras, mas devem todas ser verdadeiras.

\section{Notas}

1 O texto ganhou retoques e acréscimos do crítico para integrar o volume de ensaios Tese e antitese (1963), onde surge sob o título "Os bichos do subterrâneo".

2 Em resenha sobre o livro, então recém-editado, Lúcia Miguel Pereira (2015) já assinala a sua natureza de arte permanente, acima das contingências imediatas: "E o que lhe garante a permanência, o que lhe permitirá subjugar como a nós os leitores do futuro, para os quais serão 
quando muito vagos nomes os potentados da época sombria em que se prendia sem culpa nem processo, é a sua alta e pura qualidade literária. Documento, sim, e terrível, ele é, devendo porém o seu poder ao fato de ser, primordialmente, uma obra-prima" (Originalmente, publicado no Correio da Manhã, em 25 de dezembro de 1953).

3 Originalmente, publicado no periódico fluminense Paraiba do Sul, em 13 de maio de 1915.

\section{Referências}

CANDIDO, A. Apresentação. In: Graciliano Ramos - trechos escolbidos. Rio de Janeiro: Agir, 1960. (Col. Nossos Clássi$\cos )$.

CARPEAUX, O. M. Visão de Graciliano Ramos. In: RAMOS, G. Angústia. São Paulo: Martins, 1968.

PEREIRA, L. M. P. Memórias do cárcere. In: O Século de Camus - artigos para jornal (1947-1955). Rio de Janeiro: Graphia, 2015 .

RAMOS, P. R. Memórias do Cárcere: da literatura ao cinema. São Paulo: Alameda, 2019.

RAMOS, G. Memórias do cárcere. Rio de Janeiro: José Olympio, 1953.

Linhas tortas. São Paulo: Martins, 1970.

Erwin Torralbo Gimenez é professor de Literatura Brasileira na Universidade de São Paulo (USP). @ - torralbo@usp.br / https://orcid.org/0000-0001-9520-6308

${ }^{\text {I }}$ Faculdade de Filosofia, Letras e Ciências Humanas, Universidade de São Paulo, São Paulo, Brasil.

Recebido em 13.9.2019 e aceito em 7.10.2019. 